\title{
Comparison of Personality Traits and Demographic Factors of the Entrepreneurs: The Case of Erzincan Province
}

\author{
Fatma YILMAZ iD a Cenk AKSOY iD $b$ \\ a Erzincan Binali Yıldırım University, Üzümlü Meslek Yüksekokulu, Erzincan, Turkey. ffatmaayilmaz@gmail.com \\ b Dicle Üniversitesi, Sosyal Bilimler Enstitüsü, Diyarbakır, Turkey. drcenkaksoy@gmail.com
}

\begin{tabular}{|c|c|}
\hline ARTICLE INFO & ABSTRACT \\
\hline $\begin{array}{l}\text { Keywords: } \\
\text { Entrepreneur } \\
\text { Big five personality traits } \\
\text { Demographic factors }\end{array}$ & $\begin{array}{l}\text { Purpose - Entrepreneurship is a major force that forms the economic basis of developed countries } \\
\text { today. Entrepreneurs contribute greatly to the strengthening of the economy by using resources } \\
\text { effectively, generating innovative ideas, providing employment opportunities, and creating various } \\
\text { markets. Each of the entrepreneurial individuals has various personality traits. This study aims to } \\
\text { compare entrepreneurs' personality traits with demographic factors. }\end{array}$ \\
\hline \multirow{5}{*}{$\begin{array}{l}\text { Received } 24 \text { May } 2020 \\
\text { Revised } 9 \text { September } 2020 \\
\text { Accepted } 15 \text { September } 2020\end{array}$} & $\begin{array}{l}\text { Design/methodology/approach - The data used in the study were obtained from } 281 \text { entrepreneurs } \\
\text { who have their own business in Erzincan province between } 01.05 .2019-01.07 .2019 \text {, using the survey } \\
\text { method, which is the primary data collection tool. The Survey forms were analyzed with SPSS for } \\
\text { Windows 20.0. }\end{array}$ \\
\hline & $\begin{array}{l}\text { Findings - In the study it is found that female entrepreneurs are more extroverted than male } \\
\text { entrepreneurs while the agreeableness levels of male entrepreneurs are higher than female } \\
\text { entrepreneurs, single entrepreneurs are more extroverted than married entrepreneurs while the }\end{array}$ \\
\hline & level of conscientiousness of married entrepreneurs is higher than single entrepreneurs, \\
\hline & $\begin{array}{l}\text { young entrepreneurs were found to have more openness than older entrepreneurs. Agreeableness } \\
\text { levels of entrepreneurs with postgraduate are higher than entrepreneurs at other education levels. } \\
\text { As education increases, agreeableness increases. Conscientiousness levels of entrepreneurs with } \\
\text { postgraduate are higher than other education levels. As education increases, conscientiousness } \\
\text { increases. }\end{array}$ \\
\hline & $\begin{array}{l}\text { Discussion - It was seen that some dimensions of the personality traits of the entrepreneurs were } \\
\text { statistically significant in terms of demographic variables. Previous studies on the subject were } \\
\text { examined, similar and different results were compared with this research. In entrepreneurship } \\
\text { research, it was emphasized that personality traits and demographic factors are important and } \\
\text { should be the subject of other studies in different place time and examples in the future. Some } \\
\text { suggestions have been made to support especially women and young entrepreneurs. }\end{array}$ \\
\hline
\end{tabular}

\section{Introduction}

Entrepreneur and entrepreneurship concepts appear in many areas to increase the quality of life of individuals and countries. This concept, which has many economic, psychological, sociological, cultural, and technical dimensions, is extremely important for both countries and individuals. Society's level of development is associated with entrepreneurial activities. The development levels of the countries depend on the entrepreneurship power of the people in that country. It is observed that entrepreneurship is evaluated in a wide range from countries 'economic growth to employment, from individuals' welfare to competition strategies in the international arena.

The concept of entrepreneurship is expressed as one of the basic parameters required for the revival of the country's economy, gaining dynamism and increasing the welfare level of the country for developing and underdeveloped countries (İşcan \& Kaygın, 2011). The concept of entrepreneurship means inventiveness, which is necessary for economic development and creates innovation (Wong et al., 2005). Entrepreneurs are people, who can see opportunities compared to other people, create inventions, and introduce people with these inventions (Oosterbeek et al., 2010). Entrepreneurship is a driving force against negativities by creating innovations in rapidly changing economic conditions. Entrepreneurs contribute greatly to the strengthening 


\section{F. Y1lmaz - C. Aksoy 12/3 (2020) 2811-2822}

of the economy by using resources effectively, generating innovative ideas, providing employment opportunities and creating various markets.

When the studies on entrepreneurship are examined, it is seen that many factors are effective in the emergence of entrepreneurship. In addition to environmental and social conditions, personality traits are also important in the emergence of entrepreneurship (Frese \& Rauch, 2008). Personality traits are an extremely important factor in the development of entrepreneurship. Especially in recent years, the increase in the number of studies on 'entrepreneurial personality' clearly reveals this (Yılmaz \& Sözcan, 2019).

Many ideas have been put forward about personality traits. Studies have shown that personality studies can be compiled based on five factors. These factors (named as big five) are; extraversion, neuroticism, kindness, openness, agreeableness, and conscientiousness. Among the personality traits models developed to date, it is the big five model that is widely accepted. The big five personality theory seems to combine different views under one roof (Hough \& Ones, 2001).

Among the reasons that the big five personality model is accepted by researchers and is widely used in personality research; It can be said that (i) the model is based on longitudinal and empirical studies, (ii) the measured features continue over time, (iii) it has some biological basis, (iv) it is valid in different cultures and groups, and (v) it is easy to use and can be evaluated psychometrically (Costa \& McCrae, 1992). These personality factors have been accepted in many fields and are widely used in the field of management science. For example; It has been observed that a big five personality model is used to determine relationships in areas such as management strategies, leadership, career, organizational citizenship (Erkuş \& Tabak, 2009).

Studies on the big five personality traits of Entrepreneurs are generally discussed together with entrepreneurial tendencies, team performance, business performance, and the life span of the enterprise (Kayasandık et al., 2015). So it is not easy to find a study that compares the personality traits and demographic variables of the entrepreneurs alone. Also, the fact that the study is carried out in Erzincan, which is one of the development priority areas in the Eastern Anatolia Region of Turkey, makes the study different.

The study seeks an answer to the question that "Do the personality traits of entrepreneurs differ in terms of demographic variables?".

\section{Literature Survey}

Personality is defined as a combination of physical, mental, and spiritual characteristics that distinguish a person (Şimşek \& Akgemci, 2003). There are characteristics inherent in individuals and their environment has an effect on personality formation. The personality formed by the effect of the environment reflects the general characteristics of the human communities and the people they live in (Yelboğa, 2006).

Researchers working in the field of personality have focused on a big five personality model in order to organize personality-related approaches within a broad framework and to eliminate the confusion in the literature (Taggar et al. 1999). The big five personality model has become an open, powerful, and understandable model, developed by studying thousands of traits that people use to describe themselves and others (Hart et al., 2007). Norman Anderson stated that there are 555 traits used to describe personality traits. In the research, students studying at university were asked to indicate how much they could love an individual with existing traits. In this research carried out in 1960, it was revealed that the most loved personality trait was sincerity. When the 60 personal characteristics that are distinguished by the results of the study are ranked according to the most loved and least popular; sincere, honest, understanding, loyal, realistic, and reliable traits are in the first six places. The unrealistic, dishonest, cruel, evil, deceitful, and liar features are the first six disliked features (Güney, 2011).

Research on determining important personality traits began with Allport, continued with Cattell and Eysenck, and gained a new dimension in the early 1980s as a result of research by Robert McCrea and Paul Costa. These researchers, who researched the continuity and structure of the personality using the factor analysis method, mainly focused on the dimensions of extraversion and neuroticism. After a while, they added a new dimension called openness. Supporting a three-factor personality model, McCree and Costa concluded that the personality was five-dimensional as a result of their researches between 1983 and 1985, and added the dimensions of agreeableness and conscientiousness (İnanç \& Yerlikaya, 2011). 


\section{F. Yilmaz - C. Aksoy 12/3 (2020) 2811-2822}

Extraversion: Individuals with high extraversion dimensions are positive, social, energetic, cheerful, dominant, ambitious, and interested in others; Individuals with low extraversion dimensions are defined as shy, calm, and lonely (Bono et al., 2002). In addition, it is claimed that people with high extroverted personal qualities are sensitive to reward (Doğan, 2013). According to research, extroverted people are at a higher level than introverted people in marketing, sales and leadership positions (Özkalp, 2004). These people take part in attractive businesses and organizations and evaluate the opportunities they face. Individuals with this personality trait are people who successfully attract the attention of others and want to be blurred in social environments (Deniz \& Erciş, 2008). Costa and McCrae (1992) argue that there are six basic facets related to extraversion personality traits. These facets are; warmth, gregariousness, assertiveness, activity, excitementseeking, positive emotions.

Neuroticism: Another personality factor is neuroticism; tendency to experience negative emotions such as guilt, irritability, sadness, and fear. In this context, people with high neuroticism are anxious, insecure, withdrawn, and nervous. People with low neuroticism feel comfortable, confident, and patient (Costa \& McCrae, 1995; Bacanlı et al., 2009). They are emotionally consistent people and are balanced, calm, flexible and comfortable in dealing with other people. People with less emotional determination are more excited, anxious, and their mood can change very quickly. People with high emotional stability are better able to cope with the stress of managing others than those with low emotional stability (Özkalp, 2004). As a result of their research, Costa and McCrae (1992) formed six basic attributes related to the neurotic personality structure. These adjectives are as follows; anxiety, hostility, depression, self-consciousness, impulsiveness, and vulnerability. These people are constantly worried, depressed, experiencing at least one of the feelings of tension and anger, and experiencing the feeling of these emotions. Although their self-esteem is low, they are individuals with belief in surrealism, pessimistic feelings, having constant ups and downs in their lives, and low levels of emotional balance (Bulut, 2017).

Openness: Openness is the most cognitive feature in the big five personality traits. In this context, people who are open to high levels of development are entrepreneurial, original, creative, and curious. Those with low openness to development are considered traditional, conservative, and indifferent (Bono et al., 2002). People with a high level of openness are regarded as entrepreneurs, art-related, able to develop new ideas and productive individuals (Somer et al., 2002). As a result of their work in 1985 and 1992, McCray and Costa formed six facets about openness to experience as part of their personality structures. These facets are fantasy, aesthetics, action, feeling, ideas, and values.

Agreeableness; People with high agreeableness levels are defined as reliable, straightforward, soft-headed, self-sacrificing, and humble (Bono et al., 2002). People with high agreeableness features are empathetic, respectful and understanding. Disoriented, disappointed and grumpy people show signs of poor agreeableness (Erkuş \& Tabak, 2009). As a result of their work, McCrae and Costa formed six main facets regarding agreeableness. These facets are; trust, straightforwardness, altruism, compliance, modesty, and tender-mindedness.

Conscientiousness: This personality trait is associated with traits such as obedience, regularity, discipline, responsibility, orientation to success. While people with high conscientiousness factors are defined as ambitious and success-oriented individuals; people with low levels are defined as unplanned, undisciplined and deferral individuals (Costa \& McCrae, 1995). Conscientious persons are also disciplined. According to various research results, it has been understood that people who score high on this personality trait are more successful in both autonomous and hierarchical responsibilities (Özkalp, 2004). McCrae and Costa (1992) and Costa McCrae and Dy (1991) stated that there are six facets that measure "conscientiousness" in their work. These facets are; competence, order, dutifulness, achievement striving, self-discipline, and deliberation. These adjectives define the conscientiousness aspect of the five-factor personality traits theory, as well as trends such as working at higher performance than expected, being determined and careful, being ready for anything to solve problems, thinking carefully, and not interrupting work. As people's conscientiousness levels increase, motivation and job satisfaction also increase (Somer, 1998).

In the literature, it has been observed that the descriptive role of the personality dimensions suggested theoretically in different sample groups has been investigated (McCrae \& Costa, 1985; 1987; Hurley, 1998; 


\section{F. Yilmaz - C. Aksoy 12/3 (2020) 2811-2822}

Caligiuri, 2000; Thompson et al., 2002). Five-factor sizes have been the subject of research for various professional groups (Barrick \& Mount, 1991; Borges \& Gibson, 2005).

\section{Methods}

In the study, it was aimed at whether the demographic factors and the five-factor personality traits of entrepreneurs differ. The sample of the research; the research was carried out on people who have their own business in Erzincan. In the year of this research, 9085 entrepreneurship activities were carried out in Erzincan province (TUIK, 2019). In the research, simple random sampling was used. The questionnaires were distributed by hand between 01.05.2019-01.07.2019 and collected back. 400 questionnaires were distributed and 281 of the questionnaire forms were returned and evaluated. The questionnaire was analyzed by SPSS 20.0 package program.

Data collection tool; In order to measure personality traits, data were collected with questionnaire forms consisting of 44 questions and 4 questions for demographic characteristics and 48 questions in total. In the research, data was collected through a questionnaire developed by using various scales and questions, whose validity and reliability was tested, which were previously developed for certain purposes in the literature.

In the second part of the questionnaire form, in order to measure personality traits, there is a Big Five Inventory (BFI) developed by Benet-Martinez and John (1998) and adapted by Sümer and Sümer (2005). The scale consists of a five-point Likert type (1: never disagree, 5: absolutely agree) 44 items. There are 5 factors in the scale: extroversion, neuroticism, agreeableness, conscientiousness, openness. Extroversion dimension consists of 8 questions, neuroticism dimension 8 questions, agreeableness dimension 9 questions, conscientiousness dimension 9 questions, and openness dimension 10 questions.

The model of the study is shown in figure 1:

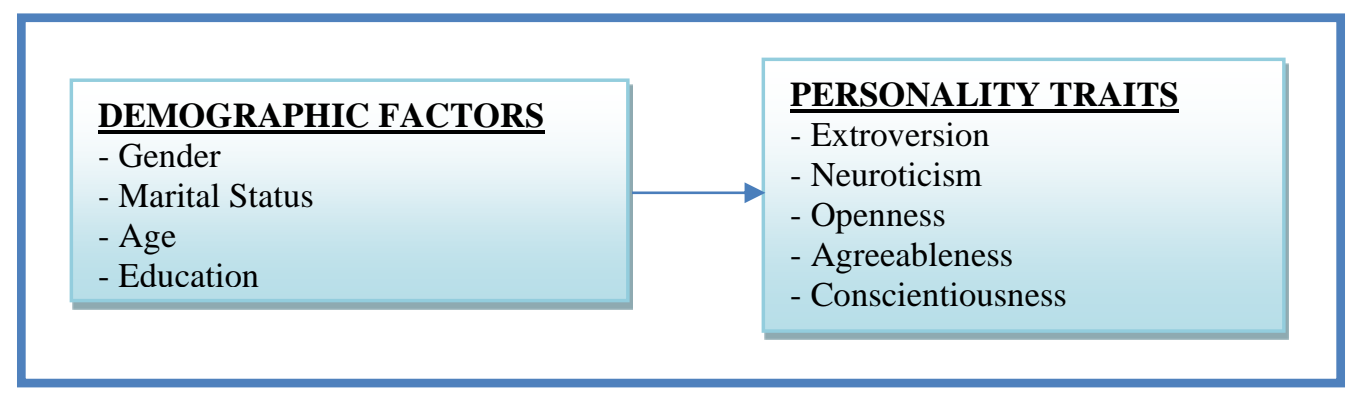

Figure 1. Research model

The hypotheses of the research are as follows:

$\mathrm{H}_{1}$ : There is a significant difference between gender factors and personality traits.

$\mathrm{H}_{2}$ : There is a significant difference between marital status and personality traits.

$\mathrm{H}_{3}$ : There is a significant difference between age and personality traits.

$\mathrm{H}_{4}$ : There is a significant difference between the education level and personality traits.

\section{Results}

In the research, the percentage and frequency analysis of the demographic variables, t-test, and ANOVA results of the participants were made.

The demographic characteristics of the entrepreneurs participating in the study are given in Table 1.

Table 1. Demographic Variables

\begin{tabular}{lcc}
\hline & Frequency & Percentage (\%) \\
\hline Gender & & \\
\hline Women & 102 & 36,3 \\
\hline Men & 179 & 63,7 \\
\hline Marital Status & & \\
\hline Married & 181 & 64,4 \\
\hline İşletme Araştırmaları Dergisi & 2814 & Journal of Business Research-Turk
\end{tabular}


F. Y1lmaz - C. Aksoy 12/3 (2020) 2811-2822

\begin{tabular}{lcc}
\hline Single & 100 & 35,6 \\
\hline Age & & \\
\hline $18-30$ & 128 & 45,6 \\
\hline $31-43$ & 58 & 20,6 \\
\hline 44 and over & 95 & 33,8 \\
\hline Educational Status & & \\
\hline Primary School & 111 & 39,5 \\
\hline High School & 82 & 29,2 \\
\hline Undergraduate & 43 & 15,3 \\
\hline Postgraduate and over & 45 & 16,0 \\
\hline Total & 281 & 100,0 \\
\hline
\end{tabular}

When Table 1 is examined; $36.3 \%$ of the entrepreneurs are women and $63.7 \%$ are men. While $64.4 \%$ are married, $35.6 \%$ are single; $45.6 \%$ of them are between the ages of $18-30,20.6 \%$ of them are between the ages of $31-43$ and $33.8 \%$ of them are over the age of $44 ; 39.5 \%$ were primary school graduate, $29.2 \%$ were high school graduate, $15.3 \%$ were undergraduate and $16 \%$ were postgraduate and over.

According to the $t$ test and variance analysis, significant differences were found between some demographic factors and the personality traits of the participants.

Looking at the group statistics, in the analysis;

Table 2. T-Test Results Regarding the Gender and Personality Traits Sub-Dimensions of Entrepreneurs

\begin{tabular}{|c|c|c|c|c|c|}
\hline Variables & Gender & $\mathbf{N}$ & $\overline{\mathbf{x}}$ & $T$ & Sig. (p) \\
\hline \multirow{2}{*}{ Extroversion } & Female & 102 & 28,2059 & \multirow{2}{*}{2,901} & \multirow{2}{*}{0,004} \\
\hline & Male & 179 & 26,6257 & & \\
\hline \multirow{2}{*}{ Neuroticism } & Female & 102 & 29,5743 & \multirow{2}{*}{1,229} & \multirow{2}{*}{0,220} \\
\hline & Male & 179 & 28,8045 & & \\
\hline \multirow{2}{*}{ Agreeableness } & Female & 102 & 28,1863 & \multirow{2}{*}{$-4,028$} & \multirow{2}{*}{0,000} \\
\hline & Male & 179 & 30,6704 & & \\
\hline \multirow{2}{*}{ Conscientiousness } & Female & 102 & 30,0392 & \multirow{2}{*}{$-0,375$} & \multirow{2}{*}{0,708} \\
\hline & Male & 179 & 30,2682 & & \\
\hline \multirow{2}{*}{ Openness } & Female & 102 & 30,1373 & \multirow{2}{*}{$-1,266$} & \multirow{2}{*}{0,207} \\
\hline & Male & 179 & 31,3352 & & \\
\hline
\end{tabular}

When the t-test results of the entrepreneurs' gender and big five personality traits are examined; A significant difference can be mentioned in extroversion and agreeableness variables $(\mathrm{p}<0.05)$. According to the averages, while female entrepreneurs are more extroverted than male entrepreneurs, the agreeableness levels of male entrepreneurs are higher than female entrepreneurs. $\mathrm{H}_{1}$ hypothesis was partially accepted as a result of significant difference between extroversion and agreeableness dimensions, and gender factor.

Table 3. T-Test Results Regarding Participants' Marital Status and Personality Traits Sub-Dimensions

\begin{tabular}{|c|c|c|c|c|c|}
\hline Variables & $\begin{array}{c}\text { Marital } \\
\text { Status } \\
\end{array}$ & $\mathbf{N}$ & $\overline{\mathbf{x}}$ & $\mathrm{T}$ & Sig. (p) \\
\hline \multirow{2}{*}{ Extroversion } & Married & 181 & 26,5138 & \multirow{2}{*}{$-3,546$} & \multirow{2}{*}{0,000} \\
\hline & Single & 100 & 28,4400 & & \\
\hline \multirow{2}{*}{ Neuroticism } & Married & 181 & 29,1381 & \multirow{2}{*}{0,251} & \multirow{2}{*}{0,802} \\
\hline & Single & 100 & 28,9798 & & \\
\hline \multirow{2}{*}{ Agreeableness } & Married & 181 & 29,6906 & \multirow{2}{*}{$-0,344$} & \multirow{2}{*}{0,731} \\
\hline & Single & 100 & 29,9100 & & \\
\hline \multirow{2}{*}{ Conscientiousness } & Married & 181 & 30,7072 & \multirow{2}{*}{2,420} & \multirow{2}{*}{0,016} \\
\hline & Single & 100 & 29,2400 & & \\
\hline \multirow{2}{*}{ Openness } & Married & 181 & 31,1326 & \multirow{2}{*}{0,685} & \multirow{2}{*}{0,494} \\
\hline & Single & 100 & 30,4800 & & \\
\hline
\end{tabular}




\section{F. Y1lmaz - C. Aksoy 12/3 (2020) 2811-2822}

When the marital status and the t-test results regarding the big five personality traits of entrepreneurs are examined; A significant difference can be mentioned in extroversion and conscientiousness variables ( $p<0.05)$. According to the averages, while single entrepreneurs are more extroverted than married entrepreneurs, the level of conscientiousness of married entrepreneurs is higher than single entrepreneurs. $\mathrm{H}_{2}$ hypothesis was partially accepted as a result of significant difference between the extroversion and conscientiousness dimensions, and marital status.

Before looking at the ANOVA Test results regarding the age and personality traits sub-dimensions of the entrepreneurs participating in the survey, the homogeneity of the variables should be checked. This situation is given in Table 4 .

Table 4. Homogeneity Test Regarding Age and Five Factor Personality Traits Sub-Dimensions of Entrepreneurs

Homogeneity Test

\begin{tabular}{lllll}
\hline & $\begin{array}{l}\text { Levene } \\
\text { Statistic }\end{array}$ & df1 & df2 & Sig. \\
\hline Extroversion & 1,164 & 2 & 278 & 0,314 \\
\hline Neuroticism & 0,827 & 2 & 277 & 0,439 \\
\hline Agreeableness & 2,482 & 2 & 278 & 0,085 \\
\hline Conscientiousness & 6,128 & 2 & 278 & 0,620 \\
\hline Openness & 2,343 & 2 & 278 & 0,098 \\
\hline
\end{tabular}

When the $p$ values of the variables are analyzed, it can be said that they are homogeneous because each variable is greater than 0.05 and in this case, the Tukey test was performed.

Table 5. T-Test Results Regarding the Age and Personality Traits Sub-Dimensions of the Participants

\begin{tabular}{|c|c|c|c|c|}
\hline Variables & Age Variable & $\begin{array}{c}\text { Mean } \\
(\overline{\mathbf{X}})\end{array}$ & $\mathbf{F}$ & Sig. (p) \\
\hline \multirow{3}{*}{ Extroversion } & $18-30$ & 27,3203 & & \\
\hline & $31-43$ & 26,5862 & 0,704 & 0,496 \\
\hline & 44 and over & 27,4105 & & \\
\hline \multirow{3}{*}{ Neuroticism } & $18-30$ & 29,1172 & & \\
\hline & $31-43$ & 28,6034 & 0,377 & 0,686 \\
\hline & 44 and over & 29,3298 & & \\
\hline \multirow{3}{*}{ Agreeableness } & $18-30$ & 29,3203 & & \\
\hline & $31-43$ & 29,5517 & 1,542 & 0,216 \\
\hline & 44 and over & 30,5053 & & \\
\hline \multirow{3}{*}{ Conscientiousness } & $18-30$ & 29,2669 & & \\
\hline & $31-43$ & 39,7414 & 6,853 & 0,001 \\
\hline & 44 and over & 31,6526 & & \\
\hline \multirow{3}{*}{ Openness } & $18-30$ & 32,5703 & & \\
\hline & $31-43$ & 30,4655 & 6,618 & 0,002 \\
\hline & 44 and over & 28,9158 & & \\
\hline
\end{tabular}

The statistically significant difference between the ages and big five personality traits of entrepreneurs is due to conscientiousness and openness dimensions. $\mathrm{H}_{3}$ hypothesis was partially accepted as a result of significant difference between the extroversion and conscientiousness dimensions, and age.

Tukey test results should be checked to understand which groups are significantly different. 


\section{F. Y1lmaz - C. Aksoy 12/3 (2020) 2811-2822}

Table 6. Tukey Test Result Regarding Age and Conscientiousness Dimension

\begin{tabular}{llll}
\hline Conscientiousness & & & \\
\hline Tukey HSD & & \multicolumn{2}{l}{ Subset for alpha $=0.05$} \\
\cline { 2 - 4 } Yaş & N & 128 & 2 \\
\hline $18-30$ & 58 & 29,2969 & \\
\hline $31-42$ & 95 & & 31,6526 \\
\hline 43 ve üzeri & &, 820 & 1,000 \\
\hline Sig. & & 5414 & \\
\hline
\end{tabular}

Conscientiousness levels of entrepreneurs aged 43 and over are higher than other age groups. Conscientiousness levels increase with age.

Table 7. Tukey Test Result Regarding Age and Openness Dimension

\begin{tabular}{llll}
\hline Openness & & & \\
\hline Tukey HSD & & \multicolumn{2}{l}{ Subset for alpha $=0.05$} \\
\cline { 2 - 4 } Age & $\mathrm{N}$ & 95 & 28,9158 \\
\hline 43 and over & 58 & 30,4655 & 30,4655 \\
\hline $31-42$ & 128 & & 32,5703 \\
\hline $18-30$ & &, 372 &, 163 \\
\hline Sig.
\end{tabular}

The openness levels of entrepreneurs who are 18 and over 30 are higher than other age groups. Young entrepreneurs were found to have more openness than older entrepreneurs.

Before looking at the ANOVA Test results regarding the education and the personality traits sub-dimensions of entrepreneurs, the homogeneity of the variables should be checked. This situation is given in Table 8 .

Table 8. Homogeneity Test Regarding Age and Five Factor Personality Traits Sub-Dimensions of Entrepreneurs

\begin{tabular}{lllll}
\hline Test of Homogeneity of Variances & \multicolumn{3}{c}{} \\
\hline & Levene & & & \\
\hline Extroversion & Statistic & df1 & df2 & Sig. \\
\hline Neuroticism &, 695 & 3 & 277 &, 556 \\
\hline Agreeableness &, 311 & 3 & 276 &, 818 \\
\hline Conscientiousness & 1,415 & 3 & 277 &, 239 \\
\hline Openness &, 302 & 3 & 277 &, 824 \\
\hline
\end{tabular}

When the $\mathrm{p}$ values of the variables are analyzed, it can be said that they are homogeneous because each variable is greater than 0.05 and in this case, the tukey test was performed.

Table 9. T-Test Results on Participants' Educational Status and Personality Traits Sub-dimensions

\begin{tabular}{llrrr}
\hline Variable & Education & $\mathbf{X}$ & F & Sig. (p) \\
\hline & Primary School & 26,8649 & & \\
Extroversion & High School & 26,8415 & & \\
& Undergraduate & 28,0930 & 1,262 & 0,288 \\
& $\begin{array}{l}\text { Postgraduate and } \\
\text { over }\end{array}$ & 27,8222 & & \\
& Primary School & & & \\
& High School & 29,1712 & & \\
Neuroticism & Undergraduate & 28,3086 & & \\
& Postgraduate and & 29,5581 & 1,082 & 0,357 \\
& over & 29,8000 & & \\
\hline
\end{tabular}




\begin{tabular}{|c|c|c|c|c|c|}
\hline Agreeableness & $\begin{array}{l}\text { Primary School } \\
\text { High School } \\
\text { Undergraduate } \\
\text { Postgraduate } \\
\text { over }\end{array}$ & and & $\begin{array}{l}28,8108 \\
29,0122 \\
30,9302 \\
32,4000\end{array}$ & 7,064 & 0,000 \\
\hline Conscientiousness & $\begin{array}{l}\text { Primary School } \\
\text { High School } \\
\text { Undergraduate } \\
\text { Postgraduate } \\
\text { over }\end{array}$ & and & $\begin{array}{l}29,0721 \\
30,3415 \\
31,1860 \\
31,6889\end{array}$ & 4,063 & 0,008 \\
\hline Openness & $\begin{array}{l}\text { Primary School } \\
\text { High School } \\
\text { Undergraduate } \\
\text { Postgraduate } \\
\text { over }\end{array}$ & and & $\begin{array}{l}29,6036 \\
30,9756 \\
30,2558 \\
34,5778\end{array}$ & 4,841 & 0,003 \\
\hline
\end{tabular}

The significant difference between the educational level of entrepreneurs and the big five personality traits is due to the dimensions of agreeableness, conscientiousness and openness. $\mathrm{H}_{3}$ hypothesis was partially accepted as a result of significant difference between the agreeableness, conscientiousness and openness dimensions, and education level. Tukey test results should be checked to understand which groups are significantly different.

Table 10. Tukey Test Result Regarding Education and Agreeableness Dimension

\begin{tabular}{|c|c|c|c|}
\hline \multicolumn{4}{|l|}{ Agreeableness } \\
\hline \multicolumn{4}{|l|}{ Tukey HSD } \\
\hline \multirow[b]{2}{*}{ Education } & \multirow[b]{2}{*}{$\mathrm{N}$} & \multicolumn{2}{|c|}{ Subset for alpha $=0.05$} \\
\hline & & 1 & 2 \\
\hline Primary School & 111 & 28,8108 & \\
\hline High School & 82 & 29,0122 & \\
\hline Undergraduate & 43 & 30,9302 & 30,9302 \\
\hline Postgraduate and over & 45 & & 32,4000 \\
\hline Sig. & & ,090 & ,365 \\
\hline
\end{tabular}

Agreeableness levels of entrepreneurs with postgraduate are higher than entrepreneurs at other education levels. As education increases, agreeableness increases.

Table 11. Tukey Test Result Regarding Education and Conscientiousness Dimension

\section{Conscientiousness}

\section{Tukey HSD}

\begin{tabular}{llll}
\hline & & \multicolumn{2}{c}{ Subset for alpha $=0.05$} \\
\cline { 2 - 4 } Education & $\mathrm{N}$ & 1 & 2 \\
\hline Primary School & 111 & 29,0721 \\
\hline High School & 82 & 30,3415 & 30,3415 \\
\hline Undergraduate & 43 & 31,1860 & 31,1860 \\
\hline Postgraduate and over & 45 & 31,6889 \\
\hline Sig. & &, 080 &, 422 \\
\hline
\end{tabular}

Conscientiousness levels of entrepreneurs with postgraduate are higher than other education levels. As education increases, conscientiousness increases. 
Table 12. Tukey Test Result Regarding Education and Openness

\begin{tabular}{llll}
\hline Openness & & & \\
\hline Tukey HSD & $N$ & \multicolumn{2}{c}{ Subset for alpha $=0.05$} \\
\cline { 2 - 4 } Education & 111 & 29,6036 \\
\hline Primary School & 43 & 30,2558 & \\
\hline High School & 82 & 30,9756 & \\
\hline Undergraduate & 45 & & 34,5778 \\
\hline Postgraduate and over & &, 747 & 1,000 \\
\hline Sig. & & & \\
\hline
\end{tabular}

Among the entrepreneurs participating in the questionnaire, those who have undergraduate education have a higher openness dimension than the other education level entrepreneurs. As education increases, openness increases.

\section{Conclusion and Discussion}

In this study, it was investigated whether there is a significant difference between personality traits and demographic factors of entrepreneurs. There is statistically significant $(p<0.05)$ differences are founded between some personality traits dimensions and demographic variables so it can be said that the hypotheses of the study are partially accepted. In the study it is found that female entrepreneurs are more extroverted than male entrepreneurs while the agreeableness levels of male entrepreneurs are higher than female entrepreneurs, similarly in the previous studies women reported higher extraversion scores than men (Weisberg et al., 2011). In contrast to the findings of the study women consistently score higher than men on agreeableness factor (Costa et al., 2001; Keskin \& Gündoğan, 2019). Single entrepreneurs are more extroverted than married entrepreneurs while the level of conscientiousness of married entrepreneurs is higher than single entrepreneurs, this situation can be evaluated as a product of the economic obligations and familial responsibilities of married workers (Solmuş, 2004). Conscientiousness levels of entrepreneurs aged 43 and over are higher than in other age groups while young entrepreneurs were found to have more openness than older entrepreneurs. Similar to this study, Rosen and Jerdee (1976) older people were perceived to be more conscientious. In contrast to the findings, younger people score higher than older ages on conscientiousness factors (Keskin \& Gündoğan, 2019). Agreeableness levels of entrepreneurs with postgraduate are higher than entrepreneurs at other education levels. As education increases, agreeableness increases. Conscientiousness levels of entrepreneurs with postgraduate are higher than other education levels. As education increases, conscientiousness increases. According to the studies supporting this situation, as the level of education increases, the opportunity to take initiative, take responsibility and make independent decisions increases (Eren, 2000).

When entrepreneurship is limited to only male entrepreneurs, a large part of entrepreneurship potential in the social sense will be ignored (Y1lmaz \& Günel, 2011). In terms of entrepreneurship characteristics, it is seen that men and women have similar characteristics. However, it is observed that women entrepreneurs have different motives, skill levels and vitality. Factors that push women to entrepreneurship have been the subject of many different studies. When the developed countries are analyzed, it is seen that the most prominent factors that direct male and female entrepreneurs towards starting their own business are the desire to be independent and to prove themselves. The driving and attractive factors are almost the same for all entrepreneurs, regardless of gender. However, the desire for flexible working conditions becomes more important for women entrepreneurs than for men entrepreneurs. One of the major factors that push women toward entrepreneurship is a flexible work opportunity that allows more household and familial duties to achieve work and family balance (Baron, 2002).

Entrepreneurship is a major force that forms the economic basis of developed countries today. Countries can diversify their economies to the extent that they shape this power, as well as maintain their economic independence and increase their welfare level with higher technologies, new products, and innovative processes in their production. At this point, it is important to provide entrepreneurship training to young brains who can realize new business ideas, create an entrepreneurial culture, and to encourage individuals in 


\section{F. Y1lmaz - C. Aksoy 12/3 (2020) 2811-2822}

this way. Entrepreneurship contributes to the development and development of the country as well as providing success to the entrepreneurs. As the entrepreneurship tendency of the young population increases, the number of entrepreneurial individuals will increase, therefore the level of development of countries will increase in direct proportion.

The importance of personality traits and entrepreneurship matters increases. In terms of entrepreneurship, it is very important for individuals to know themselves well. Entrepreneurship may mean life-long work. When an individual does not engage in entrepreneurship that suits his personality traits, perhaps he will have to deal with a job he does not like for life. Personality traits that reveal individual differences can enable us to obtain important data on entrepreneurship of individuals. Entrepreneurship, which is determined in accordance with personality traits, can be effective in making the individual happy and successful.

There were some limitations in the study. It was not possible to generalize the results since the research was conducted in a single province. Considering the universe and the sample of the study a larger scale sample can be studied. The researchers who will study on the related subject can compare the results with different variables in different places and different times.

As a suggestion in the study, practices such as providing entrepreneurship trainings, increasing consultancy services, increasing support for businesses and providing communication channels to entrepreneurs are important in terms of development of entrepreneurship in countries. Within the scope of supporting women and young entrepreneurs, many institutions and organizations should create financial models to mobilize the added value that women and young people will create for the economy. A wide range of financial support from government agencies to private banks should be the subject of either new business or existing investments to be enlarged especially by women and youth.

\section{References}

Bacanlı, H., İlhan, T., \& Aslan, S. (2009). Beş faktör kuramına dayalı bir kişilik ölçeğinin geliştirilmesi: sıfatlara dayalı kişilik testi (SDKT). Türk Ĕ̆itim Bilimleri Dergisi, 7(2), 261-279.

Baron, R.A. (2002). OB ve girişimcilik: Daha yakın kavramsal bağlantıların karşılıklı faydaları. Örgütsel Davranışta Araştırma, 24, 225-270.

Barrick, M. R., \& Mount, M. K. (1991). The big five personality dimensions and job performance: A MetaAnalysis. Personnel Psychology, 44, 1-26.

Benet-Martínez, V., \& John, O.P. (1998). Los Cinco Grandes across cultures and ethnic groups: Multitraitmultimethod analyses of the Big Five in Spanish and English. Journal of Personality and Social Psychology, 75(3), 729-750. https://doi.org/10.1037/0022-3514.75.3.729

Bono, J.E., Boles, T. L., Judge, T. A., \& Lauver, K. J. (2002). The role of personality in task and relationship confl ict. Journal of Personality, 70(3), 1311-1344.

Borges, N.J., \& Gibson, D. D. (2005). Personality patterns of physicians in personoriented and techniqueoriented specialties. Journal of Vocational Behavior, 67, 4-20.

Bulut, S.S. (2017). Beş faktör kişilik özellikleri, stresle başa çıkma ve depresyon arasındaki ilişkiler: Gazi Eğitim Fakültesi örneği. Uluslararası Türkçe Edebiyat Kültür Eğitim (TEKE) Dergisi, 6(2), 1205-1221.

Caligiuri, P.M. (2000). The big five personality characteristics as predictors of expatriate's desire to terminate the assignment and supervisorrated performance. Personnel Psychology, 53(1), 67-88.

Costa, P.T., \& McCrae, R.R. (1995). Domains and facets: Hiyerarchical personality assessment using the revised neo personality inventory. Journal of Personality Assessment, 64(1), 21-50.

Costa, P.T., Mccrae, R.R., \& Dye, D.A. (1991). Facet scales for agreeableness and conscientiousness; a revision of the neo personality inventory. Personality and Individual Differences, 12(9), 887-898.

Costa, P.T.Jr., \& McCrae, R.R. (1992). Four ways five factors are basic. Personality and Individual Differences, 13(6), 653-665. 
Costa, P.T.Jr., \& McCrae, R.R. (1992). Revised NEO Personality Inventory (NEO-PI-R) and NEO Five-Factor Inventory (NEO-FFI) professional manual. Odessa, FL: Psychological Assessment Resources.

Costa, P.T.Jr., Terracciano, A., \& McCrae, R. R. (2001). Gender differences in personality traits across cultures: robust and surprising findings. J. Pers. Soc. Psychol. 81, 322-331.

Deniz, A., \& Erciş, A. (2008). Kişilik özellikleri ile algılanan risk arasındaki ilişkilerin incelenmesi üzerine bir araştırma. Íktisadi ve İdari Bilimler Dergisi, 22(2), 301-330.

Doğan, T. (2013). Beş faktör kişilik özellikleri ve öznel iyi oluş. Doğuş Üniversitesi Dergisi, 14(1), 56-64.

Eren, E. (2000). Örgütsel Davranış ve Yönetim Psikolojisi. İstanbul: Beta Yayınları, 6. Baskı.

Erkuş, A., \& Tabak, A. (2009). Beş faktör kişilik özelliklerinin çalışanların çatışma yönetim tarzlarına etkisi: Savunma sanayinde bir araştırma. Atatürk Üniversitesi İktisadi ve İdari Bilimler Dergisi, 23(2), 213-242.

Frese, M., \& Rauch, A. (2008). A personality approach to entrepreneurship. In S. Cartwright, \& C. L. Cooper (Eds.), The Oxford Handbook of Personnel Psychology. (pp. 121-136). Oxford: Oxford University Press \& British Academy.

Güney, S. (2011). Örgütsel davranış, Ankara: Nobel Yayın Dağıtım.

Hart, J.W., Stasson, M.F., Mahoney, J.M., \& Story, P. (2007). The big five and achievement motivation: exploring the relationship between personality and a two-factor model of motivation, Individual Differences Research, 5(4), 267-274.

Hough, L.M., \& Ones, D.S. (2001). The Structure, Measurement, Validty And Use Of Personality Variables In Industrial Work And Organizational Psychology. N. Anderson, D.S. Ones, H.K. Sinangil \& C. Viswesvaran (Ed.), Handbook Of Industrial Work And Organizational Psychology içinde(Vol.1; P.233-277). Sage, London.

Hurley, J.R. (1998). Agency and communion as related to 'big five' selfrepresentations and subsequent behavior in small groups. The Journal of Psychology, 132(3), 337-351.

İnanç, B.Y., \& Yerlikaya, E.E. (2011). Kişilik kuramları. Ankara: Pegem Akademi Yayıncılık.

İşcan, Ö.F., \& Kaygın, E. (2011). Potansiyel girişimciler olarak üniversite öğrencilerinin girişimcilik eğilimlerini belirlemeye yönelik bir araştırma. Organizasyon ve Yönetim Bilimleri Dergisi, 3(2), 275-286.

Kayasandık, A.E., Güleç, R., \& Çetin, A. (2015). Beş faktör kişilik modeline göre girişimciler ve memurların kişilik farklılıklarının karşılaştııılması, 3.Örgütsel Davranış Kongresi, Tokat, Turkey.

Keskin, E., \& Gündoğan, H. (2019). Beş Faktör Kişilik Özellikleri ile İş Performansı Arasındaki İlişkiler: Beş Yıldızlı Oteller Üzerine Bir Uygulama. Uluslararası Sosyal Araştırmalar Dergisi, 12(62), 1465-1478.

McCrae, R.R., \& Costa, P.T.Jr. (1985). Updating norman's 'adequate taxonomy': Intelligence and personality dimensions in natural language and in questionnaires. Journal of Personality and Social Psychology, 49(3) 710-721.

McCrae, R.R., \& Costa, P.T.Jr. (1987). Validation of the five-factor model of personality across instruments and observers. Journal of Personality and Social Psychology, 52(1), 81-90.

Oosterbeek, H., Van Praag, M., \& Ijsselstein, A. (2010). The impact of entrepreneurship education on entrepreneurship skills and motivation. European Economic Review, 54(3), 442-454.

Özkalp, E. (2004). Örgütsel davranış (2. Bs.). Eskişehir: Anadolu Üniversitesi Web-Ofset.

Rosen, B. \& Jerdee, T. H. (1976). The nature of job-related age stereotypes, Journal of Applied Psychology, Vol. 61, pp. 180-183.

Şimşek, Ş., Akgemci, T., \& Çelik, A. (2003). Davranış bilimlerine giriş ve örgütlerde davranış, İstanbul: Adım Matbaacilik.

Solmuş, T. (2004). İş Yaşamında Duygular ve Kişilerarası İlişkiler, Beta Basım Yayım Dağıtım, İstanbul. 
F. Y1lmaz - C. Aksoy 12/3 (2020) 2811-2822

Somer, O. (1998). Türkçe'de kişilik özelliği tanımlayan sıfatların yapısı ve beş faktör modeli. Türk Psikoloji Dergisi, 13(42), 17-32.

Somer, O., Korkmaz, M., \& Tatar, A. (2002). Beş faktör kişilik envanterinin geliştirilmesi-I: Ölçek ve alt ölçeklerinin oluşturulması, Türk Psikoloji Dergisi, 17(49), 21-33.

Sümer, N., \& Sümer, H.C. (2005). Beş faktör kişilik özellikleri ölçeği (Yayınlanmamış çalışma).

Taggar, S., Hackett, R., \& Saha, S. (1999). Leadership emergence in autonomous work teams: antecedents and outcomes, Personnel Psychology, 52, 899-926.

Thompson, R.L., Brossart, D.F.V., Carlozzi, A.F., \& Miville, M.L. (2002). Five factor model (Big Five) personality traits and universal-diverse orientation in counselor trainees. The Journal of Psychology, 136(5), 561-572.

TUIK, (2019). 2019 Yılı Erzincan İli Toplam Girişim Sayısı. https://biruni.tuik.gov.tr/ilgosterge/?locale=tr

Weisberg, Y.J., De Young, C.G., \& Hirsh, J.B. (2011). Gender differences in personality across the ten aspects of the Big Five. Frontiers in Psychology, 2. https://doi.org/10.3389/fpsyg.2011.00178

Wong, P.K., Ho, Y.P., \& Autio, E. (2005). Entrepreneurship, innovation and economic growth: Evidence from GEM data. Small Business Economics, 24(3), 335-350.

Yelboğa, A. (2006). Kişilik özellikleri ve iş performansı arasındaki ilişkinin incelenmesi. ISGUC The Journal of Industrial Relations and Human Resources, 8(2), 196-217.

Yılmaz, B.S., \& Günel, Ö.D. (2011). Üniversite eğitimi ve girişimcilik: Bireyleri girişimciliğe yönlendiren etkenler üzerine bir araştırma. Akademik Bakış Dergisi, 26, 1-20.

Yılmaz, T., \& Sözcan, Z. (2019). Kişilik özelliklerinin girişimcilik eğilimi üzerine etkisi: Sakarya üniversitesi örneği. Bilgi Sosyal Bilimler Dergisi, 21(1), 78-107. 